\title{
A Human Rights Approach to Access to Land and Land Dispossession: An Examination of Ethiopian Laws and Practices
}

\author{
Demelash Shiferaw Reta $(P h D)$ \\ University of South Africa (UNISA) and Mekelle University \\ demelash.reta@gmail.com
}

\begin{abstract}
For many people, access to land is necessary to realizing human rights. Although not clearly recognized in international human rights law, the right to land might be inferred from many of its provisions. In the Ethiopian context, the Constitution guarantees access to land. However, this right is being eroded because of the government's measures to satisfy the ever-increasing demand for land through expropriation and the allocation of 'vacant' land. This article argues the former gives the government extensive power while the latter neglects traditional communal landholding system. This desk research based on literature review, legal analysis and secondary data, demonstrates how the government's actions are impinging on the human rights of the people in the rural areas and recommends reform in the land-tenure system as well as the harmonization of the subsidiary expropriation laws through the Constitution.
\end{abstract}

\section{Keywords}

access to land - human rights - land dispossession - expropriation

\section{Introduction}

Ethiopia is a developing East African country comprising various ethnic, cultural and religious groups. It is Africa's second largest populated country with more than $80 \%$ of its approximate 100 million people living in rural areas relying on agriculture. The imperative of respect, protection and fulfillment of 
human rights is formally recognized under the existing Federal Constitution of 1995 .

Clearly, human dignity is at the center of the struggle for the full realization of fundamental human rights. Access to land is crucial for the enjoyment of many of the human rights recognized in universal, regional and national instruments. Despite some efforts, access to land has not been formulated as a human right. While the essentiality of ensuring this access can be recognized, it is an unfortunate reality that many people worldwide do not have this access or else they are landless. Land dispossession is adversely affecting the lives of many poor people, especially those in developing countries. In some cases, the dispossession is carried out in the name of expropriation premised on advancing public interest through undertaking development projects and delivering public goods and services. The question remains how to reconcile public interest with the need to ensure access to land and prevent arbitrary deprivation. This article examines access to land and dispossession in light of human rights imperatives, using Ethiopia as a case study.

Accordingly, the article first explores the assumptions and principles underlying secure access to land. Secondly, it attempts to analyze existing human rights instruments to identify laws that have implicit or explicit relevance to access to land. It then discusses the practices that lead to land dispossession expropriation and other practices. It specifically discusses the meaning, conditions and procedures of expropriation and their human rights implications. To that end, the article reviews the existing literature on key concepts and analyses international and domestic legal frameworks on land rights and dispossession. The article then discusses the practices of expropriation or other acts of eviction based on secondary data, including reports of various governmental and non-governmental organizations as well as theoretical and legal framework in an effort to show its human rights implications. The article holds the expropriation laws and practices infringe upon land rights or access to land in violation of the Constitution and that culminates in arbitrary dispossession that deprives the poor of the enjoyment of fundamental human rights. Finally, it recommends legal reform and harmonization.

\section{Land and Access to Land}

This section briefly discusses the meaning and significance of land and access to land as well as the human rights dimension of these concepts based on existing universal and regional human rights frameworks. It provides a conceptual and legal background to the analysis of the Ethiopian laws and practices. 


\subsection{Land:Meaning and Significance}

Land might have different meaning and significance for different people, a point well articulated as follows:

Few people look it as an area of a ground or a structure that is not covered by water; few people look it as the area for producing grains to feed themselves, their family and their livestock. For few people the land they belong to or where they live is like their dignity, that is why most of the people look their country as their land and give it more respect than any other thing. ${ }^{1}$

Land can be seen as an object, an economic asset, a means of livelihood or a question of identity and dignity. Different disciplines also define land differently. Ambay offers a useful insight:

Land is the source of all material wealth; it provides us with all our needs to sustain on. It is also a major economic asset from which people and nations get significant profit. In many developing countries, land has been considered as an important economic and social asset where the status and prestige of people is determined. ${ }^{2}$

From legal perspective, land constitutes one form of property over which ownership or other real rights can be exercised. Property is something of value, either tangible, such as land, or intangible, such as patents and copyrights. ${ }^{3}$ Property may refer to anything that has material or moral value for human beings and may be protected by formal legal institutions. ${ }^{4}$ Clearly, legal instruments present land as a form of immovable property and consider it as the surface of the earth and any fixture on it such as buildings, fences, trees, plants

1 Vivek Kumar, The meaning of Land and its importance, 8 March 2014 [Online]. Available at https://gc21.giz.de/ibt/var/app/wp342P/1844/index.php/the-meaning-of-land-and -its-importance-3/

2 Daniel, Weldegebriel Ambay. 2013. Land rights and expropriation in Ethiopia. Doctoral thesis, School of Architecture and the Built Environment, Royal Institute of Technology (KTH), Stockholm, 30 .

3 Collins English Dictionary [Online]. Available at http://www.collinsdictionary.com/ dictionary/english/property.

4 Aubry \& Rau. 1966. Droit Civil Francis - Property. Translated by the Louisiana State Law Institute, West Publishing Co., Vol. II, 1; cited in Daniel (op. cit. n. 2), 30. 
and any improvements to the land. ${ }^{5}$ From a legal perspective, the entitlements to land - ownership or usage rights - vary from one system to another.

\subsection{Land and Access to Land as a Human Rights Issue, and Human Rights Implication}

The human rights approach considers land as an essentially human rights issue. Land is not a mere commodity, but an essential element for the realization of many human rights. ${ }^{6}$ Thanks to the relentless struggles of many, we have reached an important stage in human society: for instance, the formulation of basic human rights instruments that provide not only for the rights but also establish the institutions and procedures of enforcement or implementation though the latter remains weak. With the Universal Declaration of Human Rights (UDHR), we find the message that we should strive to realize the basic freedoms and rights using it as:

[A] common standard of achievement for all peoples and all nations, to the end that every individual and every organ of society, keeping this Declaration constantly in mind, shall strive by teaching and education to promote respect for these rights and freedoms and by progressive measures, national and international, to secure their universal and effective recognition and observance.... ${ }^{7}$

The International Bill of Human Rights and other human rights instruments underline the point that we are all born free and equal in rights and dignity. ${ }^{8}$

Ethiopia is a party to many international human rights instruments, including UDHR, the two Covenants of 1966, the Convention on the Elimination of Discrimination against Women (CEDAW) and the African Charter on Human and Peoples' Rights (ACHPR). According to article 9(4) of the Federal Democratic Republic of Ethiopia (FDRE) Constitution, these instruments form an integral part of the law of the land. More importantly, international human rights instruments are given special importance as an interpretative reference for the constitutionally recognized rights. ${ }^{9}$ We can see the interplay between

5 Daniel (op. cit. n. 2), 30.

6 United Nations Human Rights, Office of the High Commissioner [Online]. Available at http://www.ohchr.org/EN/Issues/LandAndHR/Pages/LandandHumanRightsIndex.aspx.

7 The Universal Declaration of Human Rights (UDHR), 1948, para 8.

8 UDHR, para 1 of the Preamble and article 1 . This is also reflected in ICCPR and ICESCR.

9 The FDRE Constitution, 1995, article 13(2). 
international human rights law and the Constitution, which itself devotes onethird of its provisions to protection of human rights.

Human dignity is the basic and generally agreed-upon justification for the protection of human rights. Now, we have well-established civil, political, economic, social and cultural rights as well as other emerging rights such as the right to development. These rights are generally understood as natural, universal, interrelated and interdependent. Human rights instruments also impose different obligations on states and non-state actors, with states being the primary duty bearers. One of the factors affecting the realization of fundamental rights is access to land. Without land, these rights are meaningless to many people for whom 'land rights and their protection are central to life. ${ }^{10}$ Clearly, land rights or access to land is crucial for the realization of human rights and leading a dignified life.

The realization of economic, social and cultural rights is tied to the accessibility of the land. From an economic perspective, land is a vital source of capital and provides a potential for a higher income, and so it has an impact on economic rights. ${ }^{11}$ Secure access to land provides a valuable safety net as a source of shelter, food and income in times of hardship, and a family's land can be the last available resort in the event of disaster. ${ }^{12}$ Undoubtedly, 'for rural poor people, access to productive land is an essential prerequisite for the realization of a range of human rights, including access to food, livelihood, and shelter. ${ }^{13}$ In rural areas, land is a source of livelihood and a means of satisfaction for many of the economic and social rights, including the rights to: an adequate standard of living, food, housing, health and work. Clearly, the realization of the right to food is intimately tied to the availability of land on which to grow crops. ${ }^{14}$ Of course, in both urban and rural areas individuals rely on the availability of adequate plots of land for shelter or housing. ${ }^{15}$ It is noted that:

10 Montgomery Wray Witten. 2007. The protection of land rights in Ethiopia. Afrika Focus, 20(1-2): 153-184 [Online]. Available at http://www.gap.ugent.be/africafocus/pdf/07-20-12 -Witten.pdf, 154 .

11 Elisabeth Wickeri \& Anil Kalhan, Land rights issues in international human rights law, Institute for Human Rights and Business [Online]. Available at https://www.ihrb.org/pdf/ Land_Rights_Issues_in_International_HRL.pdf, 2.

12 Wickeri \& Kalhan (supra n. 11), 2.

13 Joseph E. Stiglitz. 2009. 'Preface' in One Billion Rising: Law, Land and the Alleviation of Global Poverty (Amsterdam: Leiden University Press), 9, cited in Rebecca Tapscott. 2012. Maximizing achievements in human rights development: Arguments for a rights-based approach to land tenure reform. Praxis, The Fletcher Journal of Human Security, XxviI: 30.

14 Wickeri \& Kalhan (op. cit. n. 11), 2.

15 Ibid. 
Landlessness in the context of inadequate housing is one of the strongest indicators of poverty, hunger, and homelessness, and threatens the fulfillment of a number of human rights, including certain ESC rights, as well as access to $\mathrm{CP}$ rights. ${ }^{16}$

Clearly, access to land affects a broad range of fundamental rights. For many people, particularly for indigenous people, land is also a matter of identity and is linked to social and cultural rights. The interconnectedness and interdependence of human rights means that the non-fulfillment of socio-economic and cultural rights affects both civil and political rights.

Access to land is essential for development, poverty reduction and the realization of human rights. Unfortunately, many people do not have access to land. According to one study:

Up to one-quarter of the world's population is estimated to be landless, including 200 million people living in rural areas, and approximately $75 \%$ of the world's population living in extreme poverty (less than \$1/day) live in rural areas. ${ }^{17}$

This study reveals not only the reality of landlessness but also the correlation between landlessness and poverty and hunger. Similarly, Rebecca Tapscott notes:

Of the 1.4 billion people who live on less than $\$ 1.25$ per day, approximately 1 billion live in rural communities without secure access to land. Among this population, several hundred million are believed to lack any access to land. ${ }^{18}$

This again reaffirms that a significant proportion of the world population is landless and hence remains poor. This situation of landlessness and poverty is also worsening as more than a 'million hectares of farmland are repurposed for industrial and real estate development each year.'19

16 Tim Hanstad. 2005. 'Improving land access for India's rural poor: A review of past efforts and recommendations for the road ahead' (Rural Development Institute; New Delhi, December 2005); 2, cited in Tapscott (op. cit. n. 13), 30.

17 Secure land rights for all, UN-Habitat Global Land Tool Network 4 (2008), cited in Wickeri \& Kalhan (op. cit. n. 11), 1.

18 Rebecca Tapscott. 2012. Maximizing Achievements in Human Rights Development: Arguments for a Rights-Based Approach to Land Tenure Reform, XXVII: 26.

19 Report of the Special Rapporteur on the Right to Food, Vol. A/65/281, 2010, 6; cited in Tapscott (op. cit. n. 18), .26. 
The United Nations Food and Agriculture Agency (FAO) noted emphatically that 'rural landlessness is often the best predictor of poverty and hunger'. ${ }^{20}$ Clearly, 'secure access to land has been shown to produce positive outcomes for development indicators such as poverty reduction and improved nutrition, among others.' ${ }^{21}$ Existing evidence indicates that 'access to land is effective in helping rural households generate higher incomes through the sale of crops and the money saved when the family feeds itself from the land: ${ }^{22}$ Conversely,

a lack of secure access can relegate individuals to a cycle of poverty, in which formal landholders, government authorities, or more powerful individuals can mandate forced displacement at any time. ${ }^{23}$

It is a saddening reality that an increasing number of people are forcibly evicted or displaced from their land to make way for large-scale development or business projects such as dams, mines, oil and gas installations or ports. In many countries, the shift to large-scale farming has also led to forced eviction, displacements and local food insecurity, which in turn has contributed to an increase in rural to urban migration and, consequently, further pressure on access to urban land and housing. Forced and arbitrary dispossession has broader human rights implications, especially for people in rural areas.

\section{Access to Land: An Overview of International and National Human Rights Instruments}

A fundamental issue worth considering is be whether there is a human right to land or a right to land. There has been a long-standing peoples' quest for the recognition of a human right to land, particularly for subsistence farmers as articulated by the international farmers' movement La Via Campesina. ${ }^{24}$ Despite its significance to the realization of human rights, there is no explicit provision in the main international human rights law dealing with the right to

\footnotetext{
20 See Wickeri \& Kalhan (op. cit. n. 11), 1.

21 Tapscott (op. cit. n. 18) 26.

22 Alain De Janvry, Gustavo Gordillo, Elisabeth Sadoulet and Jean-Philippe Platteau. 2001. Access to land and land policy reforms, in Access to Land, Rural Poverty, and Public Action, 4 (Oxford University Press), cited in Wickeri \& Kalhan (op. cit. n. 11 ), 1.

23 Tapscott (op. cit. n. 18), 26-27.

24 Wray (op. cit. n. 10), 154, citing www.viacampesina.org.
} 
land. ${ }^{25}$ Nevertheless, the necessity of ensuring access to land for the realization of human rights has been reflected in several international principles and interpretive documents. $^{26}$

Obviously, a right to land is not legally codified in general international human rights instruments. ${ }^{27}$ Nevertheless, explicit rights to land have been developed in two specific areas - the rights of indigenous people and the rights of women. ${ }^{28}$

Land access has spiritual, cultural and social significance, and hence land rights have been more elaborated in the sphere of indigenous rights. ${ }^{29}$ Relevant instruments include the 1989 ILO Convention No 169 on Indigenous and Tribal Peoples and the 2007 UN Declaration on the Rights of Indigenous Peoples. The Convention, under article 14 obliges States Parties 'to identify lands traditionally occupied by indigenous peoples and guarantee ownership and protection rights. ${ }^{30}$ Land rights are also included in instruments on the rights of women, particularly the Convention on the Elimination of All Forms of Discrimination against Women (CEDAW). ${ }^{31}$

Though not explicit, general human rights instruments contain a number of land related provisions. As Wray observed 'what we find are a variety of general and specific ... human rights related to land'. ${ }^{32}$ Wickeri \& Kalhan also note 'within the international bill of human rights - namely, the UDHR and the two binding Covenants, a number of articles are directly tied to rights to land ...'33

The ICESCR stresses the recognition of 'the right of everyone to an adequate standard of living for himself and his family, including adequate food, clothing and housing, and to the continuous improvement of living conditions. ${ }^{34}$ Clearly, the realization and continuous improvement of an adequate standard of living requires the realization of its components, that is, adequate food, clothing and housing, which for many people requires access to land.

\footnotetext{
25 See Wray (op. cit. n. 10), 154 and Wickeri \&Kalhan (op. cit. n. 11), 2.

26 Wickeri \& Kalhan (op. cit. n. 11), 2.

27 Tapscott (op. cit. n. 18), 30.

28 Wickeri \& Kalhan (op. cit. n. 11), 3.

29 Ibid.

$30 \quad$ The 1989 ILo Convention No. 169 on Indigenous and Tribal Peoples, cited in Tapscott (op. cit. n. 18), 30. Nevertheless, it falls short on recognizing access to land as a human right. For arguments on this, see Tapscott (op. cit. n. 18), 31.

31 See Wickeri \& Kalhan (op. cit. n. 11), 4. See also Wray (op. cit. n. 10), 154.

32 Wray (op. cit. n. 10), 154 .

33 Wickeri \& Kalhan (op. cit. n. 11).

34 International Covenant on Economic, Social and Cultural Rights (ICESCR), 1966, article $11(1)$.
} 
Evidently, 'access to land has particularly acute ramifications for rural peoples' abilities to secure rights.' ${ }^{35}$ The right to food is tied to access to land. This right can justify and protect the right to access to land as reflected particularly in ICESCR that 'in no case may a people may be deprived of its own means of subsistence. ${ }^{36}$ The human right to adequate housing, which is therefore derived from the right to an adequate standard of living, is of central importance for the enjoyment of all economic, social and cultural rights. ${ }^{37}$ The nexus between housing and access to land is emphatically noted that: "[l]and is often a necessary and sufficient condition on which the right to adequate housing is absolutely contingent for many individuals and even entire communities. ${ }^{38}$

The interconnection between numerous other rights, including the right to food and access to land, is extensively discussed in the General Comments of the Committee on Economic, Social and Cultural rights. ${ }^{39}$ One might also consider the right to property recognized in the UDHR, which states that '(1) [e]veryone has the right to own property alone as well as in association with others [and] (2) [n]o one shall be arbitrarily deprived of his property.'40 Two important points can be emphasized: first, land might be considered part of the human right to property; secondly, the realization of this right demands the state not to arbitrarily deprive people of their right. General Comment 7 of the Committee on Economic, Social and Cultural Rights, moreover, notes that 'forced evictions are prima facie incompatible with the requirements of the [ICESCR]'.

As mentioned previously, a number of the recognized human rights are interpreted to incorporate rights to land (or access to land), including the prohibition against arbitrary dispossession. In addition, the general principles of international human rights law - the principle of equality and nondiscrimination - also provide general protections relating to access to land.

It is pertinent here to consider regional human rights systems, particularly the African Human Rights system. The main African human rights instrument the ACHPR or the Banjul Charter - does not explicitly recognize the right to

Tapscott (op. cit. n. 18), 32.

ICESCR, article 1(2). See Tapscott (op. cit. n. 18) for further discussion on how human rights provisions justify and protect access to land.

General Comment No. 4, para. 1 [Online]. Available at https://www.escr-net.org/ resources/general-comment-4.

8 Commission on Human Rights. 2005. Report of the Special Rapporteur on adequate housing as a component of the right to an adequate standard of living, Miloon Kothari, 41, U.N. Doc. E/CN.4/2005/48 (3 March 2005), cited in Wickeri \& Kalhan. (op. cit. n. 11).

9 For more on these, see General Comments 4, 12, 15, 17 in the Report of the Special Rapporteur on the Right to Food. See also Wickeri \& Kalhan. (op. cit. n. 11).

UDHR, article 17 . 
land. Nevertheless, land rights are implied from the right to property. ${ }^{41}$ The Charter provides that:

The right to property shall be guaranteed. It may only be encroached upon the interest of public need or in the general interest of the community and in accordance with the provisions of appropriate laws. ${ }^{42}$

In the Endorois Community case, ${ }^{43}$ the African Commission on Human and Peoples' Rights (ACHPR) interpreted the right to property as implying indigenous peoples' right to collective land ownership and the security and protection of communal land rights. In narrating the backgrounds to the case, Williams observed that:

the Endorois people were evicted from their traditional lands near Lake Bogoria in central Kenya in the 1970s, relocated to an area unsuitable for their pastoral way of life and granted only sporadic access to sites central to their spiritual beliefs. In the wake of the eviction, promises to provide compensation and a share of the proceeds from the nature reserve established on the Endorois' traditional lands were broken. ${ }^{44}$

The Commission highlighted that:

the first step in the protection of traditional African Communities is the acknowledgement that the rights, interests and benefits of such communities in their traditional lands constitute "property" under the Charter and that special measures may have to be taken to secure such property rights. ${ }^{45}$

This interpretation highlights the importance of recognizing and protecting customary landholding and land-use systems.

This section highlighted several important points. Firs, access to land is essential to the realization of human rights. Although specific human right to land is lacking, many provisions of international human rights instruments

\footnotetext{
41 See Wickeri \& Kalhan (op. cit. n. 11).

42 Article 14 of the African Charter on Human and Peoples' Rights and Duties, 1981.

43 The full title of the case is Centre for Minority Rights Development (Kenya) and Minority Rights Group International on behalf of Endorois Welfare Councilv Kenya.

44 Rhodri C. Williams, The African Commission 'Endorois Case' - Toward a global doctrine of customary tenure? 17 February 2010 [Online].

Ibid.
} 
can be interpreted to imply access to land. Secondly, we noted the recognition of specific land rights in relation to two specific groups - indigenous people and women. Moreover, certain general principles of international human rights laws - the principles of equality and non-discrimination - can provide general protection to ensure access to land. Furthermore, we note that international human rights law provides minimum standards of protection agreed upon by the international community. Hence, domestic legal systems play a pivotal role in ensuring access to land and prohibiting arbitrary dispossession. Finally, the Endorois case also demonstrates the importance of recognizing and protecting traditional landholding systems through the formal laws. These points are relevant in providing for a secure access to land in order to realize fundamental human rights, an issue addressed in the next section focusing on the Ethiopian legal regime.

3 Land Rights in Ethiopia

This section discusses the legal framework for the protection of land rights in Ethiopia. It considers the post-military laws, including the FD RE Constitution and other laws, against which the practices of dispossession can be analyzed.

\subsection{Land Rights in Post-military FDRE Constitution}

The multi-faceted importance of land requires states to devise appropriate policies and laws to regulate it. The absence of international norms means that the protection of land rights is left to domestic jurisdictions. Hence, there is no uniformity of laws. Land policies and laws are context-dependent, that is, they depend on the socio-economic, political and historical conditions of a particular society. For example, the transitions leading to the post-military regime in Ethiopia and the post-apartheid regime in South Africa occurred almost at the same time; but they adopted different approaches to the question of land or property. As they had different experiences; so the policies and laws on land reflect those differences.

A study of the South African Constitution reveals that property and land matters are addressed under article 25 , which does not state a specific right to property. What the Constitution does is to prohibit the arbitrary deprivation of property by providing strict criteria for depriving people of their property. ${ }^{46} \mathrm{This}$ provision might have been influenced by the negotiated nature of the transition and the underlining motive to maintain existing property rights in post-apartheid

46 The Constitution of the Republic of South Africa, 1996, section 25(1-4). 
South Africa. Moreover, there is no explicit recognition of land rights. Evidently, land falls under the ambit of property and hence the rules of maintaining the status quo also apply. So, land might be viewed as a property falling within the private domain and therefore treated as such. The Constitution does, however, recognize the importance of land restitution and reform as means of addressing historical deprivations and ensuring access to land. Irrespective of the adequacy or otherwise of the South African constitutional framework, there has been a growing public demand for restitution and to gain access to land. The 'willing-buyer willing-seller' principle that has been pursued by the government remains controversial, because of different view whether it advanced restitution or access. There is also a continuing debate about expropriation as a means of empowerment and of redressing historical injustices.

Ethiopia provides a clear land policy and laws enshrined in different policy and legal documents. The most important documents in this regard are FDRE Constitution and the ensuing subsidiary laws. The Constitution explicitly recognizes the right to property including its different components. This is incorporated under Chapter 3 dealing with fundamental rights; more specifically, under democratic rights. The rationale for situating the right to property under the category of democratic rights and the categorization of fundamental rights into human and democratic rights remain controversial. Nevertheless, the right to property is a constitutional right. The Constitution states that 'Every Ethiopian citizen has the right to the ownership of private property ... ${ }^{47}$ It provides for the widest possible ownership rights - usus, fructus and abusus rights $^{48}$ - and also defines 'private property'. ${ }^{49}$

During the constitution drafting process, there was a serious debate on the question of ownership of land. It was finally resolved that land remains a public domain; accordingly, the Constitution declares the collective ownership of land:

'The right to ownership of rural and urban land, as well as all natural resources, is exclusively vested in the State and the Peoples of Ethiopia. Land is a common property of the Nations, Nationalities and Peoples of Ethiopia and shall not be subject to sale or to other means of exchange. 50

47 FDRE Constitution, article 40(1).

48 Roman law refers to the different elements as usus (the right to use), abusus (the right to encumber or transfer), and fructus (the right to the fruits). For more on these property rights see Ilya Segal and Michael D. Whinston, Property Rights, August 7, 2010, [Online] Available at the website of Stanford University, http://web.stanford.edu/ isegal/prights.pdf.

49 FDRE Constitution, article $40(1)$ and (2).

50 Article 40(3). 
Thus, land is a constitutional matter and a common/joint property of the state and the people. Any policy advocating private ownership of land would therefore require a constitutional amendment for it to be accepted or take effect.

However, there being no private ownership of land does not mean that there is no right to the land. The Constitution recognizes the right to access to land - to utilize it and to collect its fruits. Ownership is the widest property right: individuals or people may enjoy a usufructuary right ${ }^{51}$ over a property they do not own. Hence, the Constitution states that 'Ethiopian peasants have the right to obtain land without payment and the protection against eviction from their possession.' ${ }^{52}$ In the same vein, it states that 'Ethiopian pastoralists have the right to free land for grazing and cultivation as well as the right not to be displaced from their lands. ${ }^{53}$

The Constitution therefore recognizes the importance of access to land for the wellbeing and dignity of the rural people, and for this reason it is a constitutionally guaranteed right. The human rights of the rural people can hardly be realized without having access to land. In addition, the Constitution underlines that access to land is free from payment, and necessary to ensure equity. Moreover, it places emphasis on security of landholding rights by protecting peasants and pastoralists against eviction as this practice adversely affect the lives and dignity of the rural people.

The constitution also entitles landholders to the improvements they bring about on the land; in conjunction with article 55, it also makes it clear that detailed rules are to be enacted by the federal legislature as land falls under federal jurisdiction. Regional states have the power merely to administer land according to federal legislation.

In general, we might say land is a constitutional matter rather than a policy option. While affirming common ownership of land, the Constitution recognizes important land rights in terms of access to land and secure usufructuary rights. These are important in a country where 85 per cent of the population lives off agriculture - primarily of subsistence farming. ${ }^{4}$ The Constitution is apparently inspired by the need to achieve both equity/equality in access to land and security in the holding rights. These are essential for farmers and

\footnotetext{
$51 \quad$ See Ilya Segal et al (op. cit. n. 48).

52 Article 40(4).

53 Article 40(5).

54 The Constitution is silent on access to urban land or its security. Why? While the question of access to urban land is equally important, this article focuses on the condition of rural people as they are frequent victims.
} 
pastoralists to exercise their economic, social and cultural rights as well as civil and political rights.

Like the FDRE constitution, international and regional human rights instruments also prohibit dispossession or eviction. Nevertheless, a glance at the Constitution and relevant international laws and practices reveals that dispossession is not prohibited in its entirety. What is at the centre of this article is the question of arbitrary dispossession that has a broader human rights implications and the dignified existence of many people, particularly in rural areas. This issue is addressed in the next section.

This section discusses the laws and practices that threaten access to land and its security and implications for the enjoyment of human rights. As a country with the second largest population in Africa; as a developing country trying to build infrastructure and undertake development projects; as a country with less domestic capital and technology that encourages foreign direct investment (FDI), the demand for land is ever increasing. Efforts to meet this demand often result in the displacement of farmers and pastoralists. Despite the constitutional guarantee, land rights are increasingly being eroded, to the extent of making the constitutional provisions irrelevant. The extensive resort to arbitrary dispossession resulted in what might be termed as 'land grabbing', which classically refers to the seizing of land by a nation, state or organization, especially illegally or unfairly. ${ }^{55}$ It is redefined as 'a large scale acquisition of land through purchases or leases for commercial investment by foreign organization[s].56 Therefore, land grabs are a threat to secure access to land. Moreover, there is evidence that the Ethiopian government has become part of this land-grab system by dispossessing the poor and leasing the land to domestic and foreign investors or companies. ${ }^{57}$ This practice has subjected people to arbitrary deprivation of their land, with substantial human rights implications. This deprivation and disempowerment of the rural population takes two seemingly legitimate forms of government action: expropriation and the exploitation of 'vacant' land.

55 Melkamuu Jaatee, Land rights and the violation of human rights, 26 January 2016 [Online]. Available at farmlandgrab.org.

56 Ibid.

57 Ibid. 
While recognizing the possibility and desirability of these government actions, this article holds both practices are leading to arbitrary dispossession that either diminishes or hinders the full realization of human rights.

Existing data on the allocation of farmland to investors elucidates the problem at hand. Such allocations begun in 1995, immediately after the adoption of the expropriation law, and from 2006 the demand of foreign investors for land exploitation began to increase sharply. ${ }^{58}$ Melkamuu has summarized this trend in the following terms:

More than one-third of the land allocated to investors in the ten years period was given out in 2008 . Year 2008 was a mad rush of investors to get access to land with many applicants requesting large tracts measuring more than 10000 hectares. About one million hectares of land was transferred to 500 foreign investors in the period between 2003 and 2009. The largest foreign holding is Karuturi Company of India, which has been given 0.3 million hectares of land in Gambella and 11000 in Bako district of Oromia. In 2009 and 2010, about 0.5 million hectares was allocated to investors. The land transferred to investors between 2004 and 2008 was 1.2 million hectares. ${ }^{59}$

Similar to the global phenomenon, there has been an ever-increasing demand for land, which the government was planning to address as illustrated below:

The land transferred to large-scale investors ... has been planned to increase from 0.5 million in 2011 to 2.8 million hectares in 2013, and to 3.3 million hectares in 2015 ( 15 \& 16). Total land transferred to investors will measure about $38 \%$ of land currently utilized by smallholders. Therefore, at least 7 million hectares of agricultural land was transferred to investors between 1995 and 2016. In addition, the long-term plan to expand Addis Ababa city administration at 200 kilometers radius was secretly designed by the regime until the hidden plan [was] made public in $2014 .{ }^{60}$

Where does this land come from? It comes in the form of expropriation of landholders and the allocation of 'vacant land'. Clearly, expropriation is the

\footnotetext{
$58 \quad$ Ibid.

59 Ibid.

6o Ibid. This plan was apparently reversed due to continuous public protest.
} 
chief method of government acquisition of land either for development activities or transferring to others through lease agreements. ${ }^{61}$

\subsection{Expropriation}

The preceding sections underlined the importance of access to land for the realization of human rights and the interpretative practices to connect human rights to land rights. As discussed above, the Ethiopian Constitution incorporates land rights and provides for the security of landholding rights by prohibiting eviction. But, it also provides for measures of expropriation. ${ }^{62}$ Various terminologies are used to refer to expropriation. Most civil-law countries use the term 'expropriation', whereas most common-law countries use terms such as 'eminent domain', 'compulsory sale' or 'condemnation'. Generally, expropriation or eminent domain refers to the power of a sovereign state to take or authorize the taking of private property for public purposes or use without the owner's consent but conditional upon payment in advance of commensurate/ just compensation. ${ }^{63}$

The compatibility of expropriation with secure land access can be understood in terms of the relativity of property rights. There is a necessity of striking proper balance between the right to property and legitimate public interests between security of land rights and expropriation. The Constitution allows expropriation for 'public purposes subject to payment in advance of compensation commensurate to the value of the property' ${ }^{64}$ In fact, it recognizes rather than authorize the power of expropriation as expropriation is an inherent power of the state that stems from the very existence of the state. ${ }^{65}$ Moreover, by subjecting this authority to certain requirements, it also limits this power and thereby guarantees security. Clearly, expropriation measures that violate these requirements amount to arbitrary dispossession and can therefore be rendered unconstitutional according to article 9(3) of the Constitution.

Interestingly, one might ask whether the concept of expropriation applies to land in an Ethiopian context as there is no private ownership of land. Private

61 Daniel Weldegebriel Ambaye. 2016. Urban land transfer and state monopoly in value capture in Ethiopia, Paper prepared for presentation at the 2016 World Bank Conference on Land and Poverty, The World Bank, Washington, DC, 14-18 March 2016 [Online], 7.

62 FDRE Constitution (op. cit. n. 7); article 40(8).

63 For a detailed discussion on the concept and nature of expropriation see Daniel Weldegebriel Ambaye Land rights and expropriation in Ethiopia, KTH Architecture and the Built Environment, Stockholm, 2013 (PhD dissertation).

64 Ibid.

65 Daniel Weldegebriel Ambaye. 2013. The history of expropriation in Ethiopian law. Mizan Law Review, 7(2) December: 283-284. 
property includes not only to ownership right but also usufructury right and, therefore, expropriation can apply to the latter. Expropriation in this context means dispossession of landholding rights. This is consistent with the subsidiary legislation adopted in 2005, titled 'A Proclamation to provide for the Expropriation of Land Holdings for public purposes and payment of compensation' (emphasis mine). ${ }^{66}$ This tells us, first, that landholding rights can be expropriated - the rules of expropriation do in fact apply to landholding rights. Second, it reaffirms the constitutional requirements for expropriation public purpose and payment of compensation - reflecting the security of land rights envisaged in the Constitution.

The constitutionally recognized state authority to expropriate land is further elaborated on by subsidiary legislation and bilateral investment treaties. ${ }^{67}$ Of these, the Expropriation Proclamation ${ }^{68}$ is the principal instrument governing expropriation today. The central issue of this article is to consider the implications of expropriation on land rights, especially from the perspective of small households - specifically peasants and pastoralists.

Clearly, expropriation has to satisfy the necessary conditions of public interest and compensation. To these, one may add procedural safeguards. These conditions are meant to protect landholders without unnecessarily restricting the authorities' options. However, these conditions are not easy to ascertain, and there are substantive and procedural issues that need serious consideration. First, what is public purpose? Secondly, what is compensation, how much should be paid, and how is it assessed? Thirdly, who is the decisionmaker and what is the process to be followed? Fourthly, what recourse is available to landholders who have grievances? Because of their multiple human rights implications, each of these issues must be approached with the necessary attention and care they deserve. ${ }^{69}$

66 Proclamation No. 455 of 2005 .

67 See Muradu Abdo. 2015. Reforming Ethiopia's expropriation law. Mizan Law Review, 9(2) December. These subsidiary laws include the Expropriation of Landholdings for Public Purpose and Payment of Compensation Proclamation (the Expropriation Proclamation), 2005; the Payment of Compensation for Property Situated on Landholding Expropriated for Public Purpose Regulation, 2007; the Civil Code of Ethiopia, 1960; the Urban Land Lease Holding Proclamation, 2011; and the Investment Proclamation, and Regional Rural Land Use and Administration Law.

68 Proclamation No. 455 of 2005.

69 A discussion of whether these requirements are fulfilled based on empirical research requires a study of its own. This article relies on the findings of other studies to showcase the effect on the human rights of the vulnerable. 
The requirement of public purpose or public interest is an essential constituent of expropriation. The expropriation of land is based on '... the principle that the interest of the whole community is greater than individual interest. ${ }^{70}$ This leads to the difficult question what constitutes public purpose/interest.

The different ways of understanding the term 'public purpose' can be categorized into either of the two general views - minimalist and maximalist. The minimalist view applies a strict meaning in the sense that a public purpose is deemed to exist if the expropriated property '... provide[s] its intended use to the public. The public must be entitled, as of right, to use and enjoy the property' ${ }^{71}$ Murado notes:

The minimalist conception precludes state authorities from undertaking expropriation to transfer the property of one person in order to enrich the patrimony of another, ie, taking private property for solely private purpose. The test of public purpose under this view concerns itself with the question: what is done with the expropriated property? ${ }^{72}$

The minimalist approach restricts the authority of the state to expropriate property or land rights. On the other hand, the maximalist view gives extensive power to the state by describing public purpose as

... anything which tends to enlarge the resources, increase the industrial energies and promote the productivity of any considerable number of inhabitants or a section of the state, or which leads to the growth of towns and creation of new resources for the employment of capital and labor, contributes to the general welfare and prosperity of the whole community. ${ }^{73}$

This allows a wider interpretation and gives more expropriation power to the state. This potentially affects the marginal classes extensively and may be construed as favoring the dominant class/capital. ${ }^{74}$ In this view, public interest includes not only 'uses directly beneficial to the public, such as roads, but also

70 Concept of public purpose: Its importance and usefulness in the present scenario (book chapter). Available at http://shodhganga.inflibnet.ac.in/bitstream/10603/4809o/11/11 chapter\%204.pdf.

$71 \quad$ Muradu Abdo (op. cit. n. 65).

72 Ibid.

73 Ibid.

74 Concept of public purpose: Its importance and usefulness in the present scenario (op. cit. n. 70 ). 
uses that promote the general welfare and prosperity of the whole community'.75 This approach, while allowing the state a wider scope of land acquisition to meet increasing demands for development and industrialization, has significant consequences for access to land and the realization of human rights.

The Ethiopian expropriation law incorporates both minimalist and maximalist approaches, but for different purposes. ${ }^{76}$ Some provisions of the law embody the maximalist perspective, especially when the authorities seek to expropriate land from non-investors - chiefly from peasants and pastoralists. ${ }^{77}$ The Expropriation proclamation defines 'public purpose' as

the use of land defined as such by the decision of the appropriate body in conformity with urban structure plan or development plan in order to ensure the interest of the peoples to acquire direct or indirect benefits from the use of the land and to consolidate sustainable socio-economic development. ${ }^{78}$

Also, article 3(1) of the same proclamation provides a similar meaning to public purpose by authorizing the appropriate government authority to expropriate land for 'a better development project ...' This view allows the authorities to attach the 'public purpose' label to any undertaking and accordingly its definition in rural and urban land laws is extremely broad and vague, thereby compromising its restraining power on state authority. ${ }^{79}$

However, expropriating of land from investors requires a restrictive interpretation of public purpose to mean the taking property, including land held by investors under lease, only for the purpose of undertaking publicly used projects. ${ }^{80}$ Thus, it is more difficult to expropriate land from an investor than that held by a private person.

A differentiated understanding of public purpose is a departure from previous expropriation legislation (2004 legislation) defined public purpose narrowly and uniformly without distinguishing peasants from investors. The shift appears to be motivated by the need to make expropriation easier; giving the state extensive power to dispossess small landholders in favor of capital. ${ }^{81}$ This

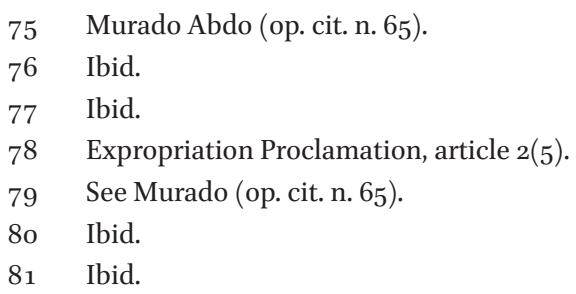


unlimited power of the state is contravening the constitutionally guaranteed rights to access to land and threatening the lives of peasants and pastoralists.

Clearly, compensation is a fundamental concern of land expropriation. ${ }^{82}$ In addition to the problem of the widening scope of public interest, there are problems with the adequacy and timing of payment of compensation to dispossessed people. ${ }^{83}$ At any rate, compensation is very low and untimely, and other measures of mitigating the effects of expropriation remain too good to be practical. The underlying thinking is that 'land remains government's property and [the] amount of compensation paid depends on government's decision. ${ }^{84}$ The land does not normally constitute a compensable interest, except in the case of substitute land. Therefore, landholders might not receive compensation for the land expropriated but only for the property situated on the land. Even then, compensation is inadequate. ${ }^{85}$

Another important consideration is whether aggrieved landholders have procedural safeguards. Unfortunately, Ethiopian expropriation laws provide very defective procedural safeguards. ${ }^{86}$ Moreover, there is no procedure of prior consultation with stakeholders - including landholders - although such consultation was an issue during the drafting of the Constitution. Considering the practice of these requirements, one clearly understands that the Ethiopian government has almost unrestricted power to dispossess landholders.

While not disapproving all expropriation measures, this article argues the notion of expropriation has been used to legitimize arbitrary dispossession, resulting in increased incidence of 'land grabs'. Whatever terminology is used, the central point is that people have been arbitrarily dispossessed from their land, with serious human rights implications for pastoralists and farmers.

82 Gashaw Tenna Alemu. 2015. Land expropriation and compensation payment in Ethiopia: Review. Journal of Economics and Sustainable Development, 6(13): 94. Available at www .iiste.org file:///C:/Users/retads/Downloads/24279-26855-1-PB.pdf.

83 For an elaborate discussion, see Murado (op. cit. n. 65). The insufficiency relates to different aspects of the law, including the problems of: compensable interest, displacement compensation; substitution of land; lack of uniformity; ascertaining landholders, and implementation matters.

84 Gashaw Tenna (op. cit. n. 80), 94.

85 Daniel Weldegebriel Ambaye, Urban land transfer and state monopoly in value capture in Ethiopia, Paper prepared for presentation at the 2016 World Bank Conference on Land and Poverty, The World Bank, Washington, DC, 14-18 March 2016 [Online], 12.

86 Murado (op. cit. n. 65). The expropriated cannot contest certain aspects of decisions of the authorities, either in an administrative or a judicial forum. 


\subsection{The Notion of Vacant Land and Dispossession}

The government's other mechanism of satisfying the ever-increasing demand is through the acquisition of vacant land with the claim a large proportion of land remains unoccupied or uninhabited and unused. This rationale seems to make unused or underused land available for development projects, public use or investment. In property law, the concept of res nullius ('a thing without owner' or 'nobody's land') entitles the occupier. A related concept is terra nullius, a legal doctrine traceable to the Roman-law principle of res nullius, which came to describe all land beyond the imperial boundaries; it was applied in the context of imperial territorial expansions. ${ }^{87}$ In Romanocentric jurisprudence, these lands were by definition not 'owned' by anyone and were fair game for annexation. ${ }^{88}$ Considering the current land question and land use in Africa, Geisler notes that

informal expressions of terra nullius are thriving ... with immediate relevance to contemporary Africa ... these narratives are surfacing as partial justification for what [is] called the "great global enclosure of our time".89 The central point is that the doctrine continues to be used as a pretext for control if not ownership in distant lands ... and as a legal tool of the global north; more importantly, it is reappearing in potent de facto forms that have to be acknowledged and which are facilitating the spread of African land claims by non-Africans. ${ }^{90}$

The idea may have relevance in today's practices of dispossession of communal land. However, the notion of vacant land or unoccupied land is disputable in Ethiopia because there are informal or communal landholding systems even if formal laws do not recognize them. Is there unoccupied/unused land? An answer to this question should relate to the question of land rights and land use. What does 'landholder' mean in the Ethiopian context? How many Ethiopian farmers and pastoralists have certificates/title to the land? More importantly, does the law recognize customary landholding rights or is it premised on the liberal philosophy of individualism?

87 Charles Geisler. 2012. New Terra Nullius narratives and the gentrification of Africa's 'empty lands', American Sociological Association, XVIII: 1-2.

88 Geisler (op. cit. n. 88), 18.

89 Ibid.

9o Geisler (op. cit. n. 88), 15 . 
As a general point, land tenure and the use of land is regulated by both formal and informal laws. ${ }^{91}$ In this respect, it is noted that

Across much of the developing world, customary and local norms dominate land management. The World Bank estimates that across Africa, less than 10 percent of land is held under formal land tenure, most of which is urban rather than rural..$^{92}$

The formal land-tenure system focuses on the individualist conception of ownership, whereas informal or customary systems often focus on communityoriented holding and use rights. ${ }^{93}$ To the extent that the formal system focuses on individual holding and use, it excludes communal holding and use rights and might give rise to the perception of communal land being vacant.

The idea of vacant land has been espoused by the Ethiopian government in order to make land available for various purposes, from public projects to investment ventures. The expropriation law has created such an idea in providing a technical definition of who a landholder is. The law provides for the payment of compensation to holders of expropriated land, such a holder being defined as 'an individual ... [who] has lawful possession over the land to be expropriated ...'94 Such an individualistic conception of landholders has major implications on the lives and livelihoods of many who rely on a customary or traditional communal landholding system. ${ }^{95}$ It is emphatically stated that 'shifting property rights can curtail access to land for certain people, and allow economically, socially, or politically powerful players to exploit the system for personal gain'.96 The formal law is allowing rural communal landholders to be dispossessed of their land, adversely affecting their very existence. It leads to the exclusion and marginalization of the rural people. The law should in principle be formulated broadly along the lines of the 1960 Civil Code, that is, in such a manner that any person who establishes the existence of a property right in their favor over the land expropriated is given the opportunity

\footnotetext{
91 Tapscott (op. cit. n. 18), 30.

92 Ibid., citing Lorenzo Cotula et al. 2011. Agricultural investment and international land deals: Evidence from a multi-country study in Africa, Food Security 3(1) February: 100.

93 Tapscott (op. cit. n. 18), 30.

94 Articles 5(2), 2(3) and 13(1) of the Expropriation Proclamation, cited in Murado (op. cit. n. 65). Article 22 of the Expropriation Regulations also provides a similar definition of landholders - one who "produces 'proof of legitimate possession ....'

95 See Murado (op. cit. n. 65), 318.

96 Tapscott (op. cit. n. 18), 30.
} 
to demand compensation. ${ }^{97}$ More broadly, 'security in land rights has the potential to help develop equitable relations among social groups, thereby contributing to justice, peace, and sustainable development. ${ }^{98}$ The exclusion of customary land rights from the purview of expropriation procedures is therefore problematic. Fundamentally, '... the use of the power of eminent domain is depriving people not recognized as owners of the land of their means of subsistence. Tenants, herders, and agricultural laborers are among those paying the highest social cost of expropriation because they are not recognized as holding any property rights. ${ }^{\prime} 9$

Here, we need to remember the decision of the African Commission on Human and Peoples' Rights in the Endorois Community case based on the African Charter on Human and Peoples' Rights. As Ethiopia is a party to this charter, the Ethiopian laws should be viewed in the light of the regional human rights instrument and institution as envisaged under article 13(2) of the FDRE Constitution. The idea of vacant land is used to dispossess traditional landholders and diminishes their potential to exercise the fundamental human rights recognized under national and international human rights instruments.

\section{5 Concluding Remarks: Human Rights Implications of Dispossession}

The significance of access to land for the realization of human rights, particularly for people in the rural areas, is beyond doubt. Unfortunately, despite continuing efforts to rectify the lacuna in international human rights law, such law does not incorporate an explicit right to land. Although the notion of secure access to land is emerging in the area of indigenous peoples' rights and women's rights and the norms arising from the interpretative practices of human rights bodies, the question of access to land is currently left largely to domestic policies and laws to regulate.

The Ethiopian Constitution, apart from declaring land as a joint property of the people and the government, provides that Ethiopian farmers and pastoralists have the right to obtain land for use - farming and grazing - free of payment. There is an essential constitutional right to secure access to land. This is very important for a country with the largest proportion of its population living in rural areas and dependent on agriculture. Despite these constitutional protections, because of the ever-increasing demand for public projects,

\footnotetext{
$97 \quad$ Murado (op. cit. n. 65), 318.

98 Tapscott (op. cit. n. 18) 30.

99 Antonio Azuela \& Carlos Herrera-Martin 358, cited in Murado (op. cit. n. 65), 318.
} 
investment and other enterprises, the Ethiopian government is resorting to land-acquisition mechanisms that violate the constitutional right to access to land and hence impinge upon the realization of human rights in the country.

Enabling such violations of the Constitution and human rights is the Ethiopian expropriation laws, which give extensive power to the government and which afford farmers and pastoralists little or no practical protection against land dispossession. The broader interpretation of public purpose and the inadequacy of compensation coupled with the inadequacy of existing remedies are eroding and destroying the human rights and the very existence of many farmers and pastoralists. The idea of vacant or unused land is being used to disempower and dispossess people of their communal land-use right.

Clearly, two areas of intervention are required to remedy the problem. First, the expropriation laws should be revised to impose strict conditions on the government to protect farmers and pastoralists against arbitrary land dispossession. Second, the laws should recognize traditional communal landholding system because without such recognition many more rural people will become landless, and their fate will have broader implications regarding the realization of their human and constitutional rights. 